\title{
$\left.{ }^{18} \mathrm{~F}\right]$ 2-Fluoro-2-deoxy-D-glucose incorporation by AGS gastric adenocarcinoma cells in vitro during response to epirubicin, cisplatin and 5-fluorouracil
}

\author{
SA Suttie', KGM Park' and TAD Smith*,2 \\ 'Department of Surgery, School of Medical Sciences, University of Aberdeen, Foresterhill, Aberdeen AB25 2ZN, UK; ${ }^{2}$ John Mallard PET Centre, \\ Department of Biomedical Physics, School of Medical Sciences, University of Aberdeen, Foresterhill, Aberdeen AB25 2ZN, UK
}

Decreased tumour [ $\left.{ }^{18} \mathrm{~F}\right]$ 2-fluoro-2-deoxy-D-glucose $\left({ }^{18} \mathrm{FDG}\right)$ incorporation is related to response however its significance at the cell level in gastro-oesophageal cancer and how it relates to cell death is unknown. Here human gastric adenocarcinoma (AGS) cells were treated with lethal dose 10 and 50 (LD 10 and $L_{50}$ ), determined by using the MTT assay, of the three drugs, epirubicin, 5-fluorouracil and cisplatin, commonly used in the treatment of patients with gastro-oesophageal cancer. ${ }^{18} \mathrm{FDG}$ incorporation was determined after 48 and $72 \mathrm{~h}$ of treatment with each drug and related to drug-induced changes in glucose transport, hexokinase activity, cell cycle distribution and annexin V-PE binding (a measure of apoptosis). Treatment of cells for 48 and $72 \mathrm{~h}$ with LD 50 doses of cisplatin resulted in reductions in ${ }^{18} \mathrm{FDG}$ incorporation of 27 and $25 \%$ respectively and of 5 -fluorouracil reduced ${ }^{18}$ FDG incorporation by 34 and $33 \%$ respectively: epirubicin treatment reduced incorporation by 30 and $69 \%$ respectively. Cells that had been treated for $72 \mathrm{~h}$ with each drug were incubated in drug-free media for a further 6 days to determine their ability to recover. Comparison of the ability to recover from the chemotherapy agent, with ${ }^{18}$ FDG incorporation before the recovery period allowed an assessment of the predictive ability of ${ }^{18} \mathrm{FDG}$ incorporation. Cells treated with either 5 -fluorouracil or cisplatin demonstrated recovery on removal of the drug. In contrast, cells treated with epirubicin did not recover corresponding with the greatest $72 \mathrm{~h}$ treatment decrease in ${ }^{18} \mathrm{FDG}$ incorporation. In contrast to adherent cells treated with cisplatin or 5-fluorouracil, adherent epirubicin-treated cells also exhibited very high levels of apoptosis. Glucose transport was decreased after each treatment whilst hexokinase activity was only decreased after $72 \mathrm{~h}$ of treatment with each drug. There was no consistent relationship observed between ${ }^{18}$ FDG incorporation and cell cycle distribution. Our results show that at the tumour cell level in gastric tumour cells, decreased ${ }^{18}$ FDG incorporation and glucose transport, accompanies therapeutic growth inhibition. ${ }^{18} \mathrm{FDG}$ incorporation is particularly diminished in cells exhibiting apoptosis. British Journal of Cancer (2007) 97, 902-909. doi:10.1038/sj.bjc.660397I www.bjcancer.com

Published online II September 2007

(c) 2007 Cancer Research UK

Keywords: glucose transport; hexokinase; FDG-PET; apoptosis; gastric

Combination chemotherapy may improve the length and quality of survival in a proportion of patients with advanced gastrooesophageal cancer. With currently available chemotherapy regimens, only $40-60 \%$ of patients will respond to treatment (Gilbert et al, 2002). Present chemotherapy regimens for gastro-oesophageal cancer include epirubicin, cisplatin and 5-fluorouracil (5-FU). If patients are to avoid unnecessary treatment with particularly toxic agents, it is important that non-responders are identified at an early stage.

A number of studies (Couper et al, 1998; Weber et al, 2001; Kroep et al, 2003; Ott et al, 2003) have demonstrated that a reduction in tumour uptake of the glucose analogue, $\left[{ }^{18} \mathrm{~F}\right] 2$-fluoro2-deoxy-D-glucose $\left({ }^{18} \mathrm{FDG}\right)$, is observed during and upon completion of chemotherapy in gastro-oesophageal cancer. Although decreased tumour ${ }^{18}$ FDG uptake has been shown to be associated with response (and may in fact predict tumour response), its

*Correspondence: Dr TAD Smith; E-mail: t.smith@biomed.abdn.ac.uk Revised I8 July 2007; accepted I3 August 2007; published online II September 2007 significance at the gastro-oesophageal tumour cell level is not known. Response to chemotherapy, as seen on ${ }^{18}$ FDG-PET with a corresponding reduction in uptake in solid tumours, may be related to a decrease in tumour cellularity or a decrease in ${ }^{18} \mathrm{FDG}$ uptake per cell, or a combination of both. In solid tumours, tumour cells can recover and it is not known if this decreased ${ }^{18} \mathrm{FDG}$ uptake during response is due to modulation in ${ }^{18} \mathrm{FDG}$ uptake by cells that will not recover. This reduction in cellular uptake of ${ }^{18} \mathrm{FDG}$ may occur prior to reduction in tumour volume and therefore may reflect apoptosis. To further confuse matters, a flare phenomenon has been recorded in the early period following exposure to chemotherapy (Basu and Alavi, 2007). In addition chemotherapy may alter ${ }^{18}$ FDG cellular uptake by hexokinase (HK) and/or glucose transport modulation.

The fluorinated glucose analogue, ${ }^{18} \mathrm{FDG}$, is transported into tumour cells via a family of glucose transporter proteins, then phosphorylated by the enzyme HK to ${ }^{18}$ FDG-6-phosphate after which it undergoes little further metabolism. Due to low levels of G-6-Pase in tumour cells this is considered an irreversible reaction (Weber and Cantero, 1955; Warburg, 1956; Gallagher et al, 1978). 
Higher levels of HK, namely, HK2 (Torizuka et al, 1995; Mathupala et al, 1997) and GLUT, especially GLUT1 (Mueckler, 1994; Younes et al, 1996; Smith, 1999) and low levels of G-6-Pase (Nelson et al, 1996) have been reported in tumour tissue compared with corresponding normal tissue. Both glut proteins and $\mathrm{HK}$ activity have been implicated as the rate limiting step in cellular ${ }^{18} \mathrm{FDG}$ uptake (Higashi et al, 1997; Waki et al, 1998; Brown et al, 1999; Kurokawa et al, 2004; Tohma et al, 2005; Zhao et al, 2005), although plasma (or media) glucose concentrations may have more of an impact (Aloj et al, 1999; Zhao et al, 2002; Burrows et al, 2004).

We have determined the effect of three commonly used chemotherapeutic agents (epirubicin, cisplatin and 5-FU) in the treatment of upper gastro-intestinal tumours on the cellular incorporation of ${ }^{18} \mathrm{FDG}$ and on steps associated with its incorporation, that is, glucose transport and $\mathrm{HK}$ activity. As tumour cells within solid tumours are likely to be exposed to different drug concentrations, we have treated cells with both lethal dose $50\left(\mathrm{LD}_{50}\right)$ and drug doses that have a low cell growth inhibition ( $\mathrm{LD}_{10}, 5-10 \%$ cell death). Previous work on AGS (human gastric adenocarcinoma) cells has shown that they can recover from treatment with cytotoxic doses of combinational regimes of 5-FU and cisplatin but not when epirubicin is included in the combination (Couper and Park, 2003). However, the design of Coupers' study meant that this effect could not be specifically related to epirubicin rather than triple combination chemotherapy. Our study evaluated the effect of each individual chemotherapeutic agent. Growth curves for AGS cells were established after exposure to each epirubicin, cisplatin and $5-\mathrm{FU}$, with $\mathrm{LD}_{10}$ and $\mathrm{LD}_{50}$ established for each agent at $48 \mathrm{~h}$. Growth curves were taken to $216 \mathrm{~h}$ to determine the extent to which cells were irreversibly damaged by the chemotherapeutic agents. All subsequent experiments on ${ }^{18}$ FDG uptake and its relationships to glucose transport, $\mathrm{HK}$ activity, cell viability, cell cycling and apoptosis were undertaken at 48 and $72 \mathrm{~h}$.

The aims of this study were to elucidate the effect, on cellular (AGS cells) ${ }^{18}$ FDG incorporation, of exposure to three commonly used chemotherapeutic agents in the treatment of gastrooesophageal cancer and to determine the mechanisms behind these changes in ${ }^{18} \mathrm{FDG}$ cellular incorporation and their relationship with apoptosis.

\section{MATERIALS AND METHODS}

\section{Cell line}

A human gastric adenocarcinoma cell line (AGS) (ECACC, Porton Down, Salisbury, UK) was cultured in HAM F-12 media (Sigma, Dorset, UK) (supplemented with sodium hydrogen carbonate, penicillin G, streptomycin sulphate and L-glutamine and 10\% fetal calf serum (Labtech International, East Sussex, UK)) at $37^{\circ} \mathrm{C}$ in a humidified incubator with $5 \% \mathrm{CO}_{2}: 95 \%$ air.

The cells were subcultured in vented $80 \mathrm{~cm}^{2}$ flasks (Nunclon Delta Surface, Roskilde, Denmark). Cell suspensions were obtained by trypsinisation (ethylenediaminetetraacetic acid (EDTA)/trypsin) (Sigma) of the adherent cell monolayer, with $5 \mathrm{ml}$ of EDTA/ trypsin, when cells reached $70-80 \%$ confluence. Cell counts were performed using a haemocytometer (Bright-Line Haemocytometer, Sigma).

A seeding density of 7500 cells per $0.35 \mathrm{~cm}^{2}$, based on previous work (Couper and Park, 2003), was used for all experiments.

\section{Cytotoxicity assays}

These were performed to identify the $\mathrm{LD}_{10}(5-10 \%$ cell death) and $\mathrm{LD}_{50}$ doses of three chemotherapeutic agents, commonly used in the treatment of gastro-oesophageal cancers, using the MTT (3(4,5-dimethylthiazol-2-yl)-2,5-diphenyl tetrazolium bromide) assay (Mosmann, 1983; Carmichael et al, 1987).

Cells were plated in HAM F-12 media, at optimal seeding density, and returned to the incubator for $24 \mathrm{~h}$ to allow cell adherence to the plate. Media supplemented with varying concentrations of the chemotherapeutic agents epirubicin (Pharmacia and Upjohn Ltd., Milton Keynes, UK) $\left(0.0039-0.5 \mu \mathrm{g} \mathrm{ml}^{-1}\right)$, cisplatin (Faulding Pharmaceuticals, Warwickshire, UK) (0.156$20 \mu \mathrm{g} \mathrm{ml}^{-1}$ ) and 5-FU (Faulding Pharmaceuticals) (0.156$80 \mu \mathrm{g} \mathrm{ml}^{-1}$ ) was then added and the plate returned to the incubator for either 48 or $72 \mathrm{~h}$. A background of media and a control of media and cells were also set up.

After 48 or $72 \mathrm{~h}$ of exposure to the chemotherapy agents, MTT (Sigma) was added and then incubated for a further $4 \mathrm{~h}$ at $37^{\circ} \mathrm{C}$. Using a scanning multi-well spectrophotometer (Dynatech MR5000, Dynatech Labarotaries Inc., Chantilly, VA, USA) measuring spectrophotometric absorbance at $570 \mathrm{~nm}$, the plates were analysed using Biolinx 2.0 software (Biolinx 2.0, Dynatech Labarotaries Inc.). All experiments were repeated three times with six replicates per experiment. All subsequent cell work was based on the $\mathrm{LD}_{10}$ and $\mathrm{LD}_{50}$ concentrations of the chemotherapy agents at $48 \mathrm{~h}$ so that time was the only variable.

\section{Quantifying ${ }^{18} \mathrm{FDG}$ uptake}

Cells were seeded and incubated for $24 \mathrm{~h}$, with control flasks were seeded at half the optimum seeding density so that cell density was similar in the control and treated flasks at the time of the ${ }^{18} \mathrm{FDG}$ uptake measurement. Control, $\mathrm{LD}_{10}$ and $\mathrm{LD}_{50}$ flasks were set up in triplicate and the corresponding concentrations of each chemotherapeutic agent and returned to the incubator for either 48 or $72 \mathrm{~h}$. The incorporation of ${ }^{18}$ FDG (obtained from the John Mallard PET Centre, Aberdeen) was determined by incubation of treated and control cells with ${ }^{18} \mathrm{FDG}\left(1 \mathrm{kBq} \mathrm{ml}{ }^{-1}\right)$ for $20 \mathrm{~min}$ at $37^{\circ} \mathrm{C}$ followed by rapid washing with phosphate buffered saline (PBS) as described previously (Smith et al, 2006). ${ }^{18}$ FDG uptake was expressed relative to protein content (milligram of cellular protein) and per treated flask.

\section{Protein assay}

Protein content was assessed by the bicinchoninic acid protein assay kit according to the manufacturers' instructions (Sigma).

\section{Glucose transport}

Initially the linear phase of $\left[{ }^{3} \mathrm{H}\right] \mathrm{O}$-methylglucose $\left({ }^{3} \mathrm{H}-\mathrm{OMG}\right)$ uptake, a measure of glucose transport (Cloherty et al, 2002), was determined by incubating cells with ${ }^{3} \mathrm{H}-\mathrm{OMG}$ for $1,2,3,5,15$ and $30 \mathrm{~s} .{ }^{3} \mathrm{H}-\mathrm{OMG}$ uptake in control AGS cells was very rapid, with the linear part of the time activity curve for ${ }^{3} \mathrm{H}-\mathrm{OMG}$ uptake at $37^{\circ} \mathrm{C}$ complete within $2 \mathrm{~s}$ of beginning incubation. Experiments were, therefore, conducted at $25^{\circ} \mathrm{C}$ with an exposure to ${ }^{3} \mathrm{H}-\mathrm{OMG}$ of $1 \mathrm{~s}$.

Glucose transport rates were determined at both 48 and $72 \mathrm{~h}$ following the addition of required dose of chemotherapeutic agent, by incubation with media and ${ }^{3} \mathrm{H}-\mathrm{OMG}\left(0.5 \mu \mathrm{Ci} \mathrm{ml}^{-1}\right.$ (specific activity $111 \mathrm{GBq} \mathrm{mmol}^{-1}$ )), at $25^{\circ} \mathrm{C}$ as described previously (Smith et al, 2006) except that the incubations were performed for $1 \mathrm{~s}$. ${ }^{3} \mathrm{H}$-OMGuptake was expressed in terms of protein content (milligram of cellular protein).

\section{Hexokinase activity assay}

AGS cells were set up and treated with chemotherapy as per ${ }^{18}$ FDG uptake. Following the incubation for 48 or $72 \mathrm{~h}$ with chemotherapy the media was removed, and each flask was washed twice with 
ice-cold PBS. Cells were then trypsinised and centrifuged with the cell pellet washed a further two times with ice-cold PBS. The resulting cell pellet was then stored at $-70^{\circ} \mathrm{C}$ until the $\mathrm{HK}$ activity was assessed based on a modification to the methods by Miccoli et al (1996) as described previously (Smith et al, 2006).

Enzyme activity was expressed as $\mathrm{mU} \mathrm{mg}^{-1}$ cellular protein using the extinction coefficient for NADPH of $6.3 \times$ $10^{3} \mathrm{~mol}^{-1} \mathrm{~cm}^{-1}$.

\section{Flow cytometry DNA quantification}

AGS cells were set up and incubated in chemotherapy as previously described for ${ }^{18} \mathrm{FDG}$ uptake. After the required incubation period the media was discarded and the cells were harvested and cell cycle distribution was determined as described previously (Al-Saeedi et al, 2005).

\section{Cell regrowth following exposure to chemotherapy}

Cells were plated as for MTT assay and treated for $72 \mathrm{~h}$ with $\mathrm{LD}_{50}$ and $\mathrm{LD}_{10}$ doses of each chemotherapy agent. Following this, the media was removed and the cells were washed with warm $\left(37^{\circ} \mathrm{C}\right) \mathrm{PBS}$ to remove any traces of residual chemotherapy. Fresh media (without chemotherapy) was then added and the plates were returned to the incubator. After $24,48,72,96,120$ and $144 \mathrm{~h}$ incubation, MTT assays were performed to determine the latent cytotoxicity of the chemotherapeutic agents. Each experiment was repeated in triplicate with six replicates for each agent and time point.

\section{Annexin V-PE flow cytometry}

Annexin V flow cytometry was used to discriminate between intact cells, early apoptotic and late apoptotic or necrotic cells.

AGS cells were set up as per ${ }^{18}$ FDG uptake. Control and cells treated for $72 \mathrm{~h}$ with chemotherapy agents were detached by incubating the cells in non-enzymatic cell dissociation solution in PBS (Sigma) and added to fresh media. The cell concentration was then adjusted to $3 \times 10^{5} \mathrm{cells} \mathrm{ml}^{-1}$, and $1 \mathrm{ml}$ of this cell suspension was then transferred to FACS tubes and centrifuged. The cell pellet was re-suspended in $1 \mathrm{ml}$ of binding buffer $(140 \mathrm{~mm}$ sodium chloride, $25 \mathrm{~mm}$ calcium chloride, $10 \mathrm{~mm}$ HEPES ( $N$-(2-hydroxyethyl)piperazine- $N^{\prime}$-(2-ethanesulphonic acid) hemisodium salt), $500 \mathrm{ml}$ distilled water; Sigma). Following further centrifugation and removal of the supernatant, $15 \mu \mathrm{l}$ of annexin V staining buffer (10 $\mu \mathrm{l}$ Via-Probe (7-N actinomycin D), $5 \mu \mathrm{l}$ annexin V-PE) (BD Biosciences Pharmingen, Oxford, UK) was added to each cell sample. The samples were stored in the dark at room temperature for $15 \mathrm{~min}$ after which $400 \mu \mathrm{l}$ of binding buffer was added and annexin V flow cytometry was performed within $1 \mathrm{~h}$, analysing 10000 cell events.

Annexin V flow cytometry was performed on a Becton Dickinson FACS Calibur (San Jose, CA, USA), and results analysed using CellQuest software (Becton Dickinson).

\section{Statistics}

Results are expressed as means, \pm s.e.m.. ${ }^{18} \mathrm{FDG},{ }^{3} \mathrm{H}-\mathrm{OMG}$ uptake and HK activity were expressed as a percentage of the control. Significance of difference between means was determined by using the paired $t$-test (Statistical Package for the Social Sciences V13.1, SPSS Inc., Chicago, IL, USA), with a $P$-value of $<0.05$ indicating statistical significance.

\section{RESULTS}

\section{Cytotoxicity assay}

Cytotoxic doses resulting in a 5-10\% decrease in cell number $\left(\mathrm{LD}_{10}\right)$ and $\mathrm{LD}_{50}$ doses of chemotherapy after $48 \mathrm{~h}$ exposure were for cisplatin 0.156 and $5 \mu \mathrm{g} \mathrm{ml}^{-1}, 5$-FU 0.156 and $20 \mu \mathrm{g} \mathrm{ml}^{-1}$ and epirubicin 0.0039 and $0.125 \mu \mathrm{g} \mathrm{ml}^{-1}$ respectively (Table 1 ).

\section{Effect of chemotherapy on ${ }^{18}$ FDG uptake}

${ }^{18}$ FDG uptake per untreated control flask (expressed as cpm per 20 min per flask) was $8714 \pm 1182$ and $14753 \pm 986$ respectively after 48 and $72 \mathrm{~h}$ incubation periods. ${ }^{18}$ FDG uptake, expressed as counts per milligram of cells per minute in untreated control flasks, was $783 \pm 94$ and $984 \pm 35$ (cpm per 20 min per mg protein) respectively following 48 and $72 \mathrm{~h}$ incubation periods.

All three chemotherapeutic agents caused a reduction in ${ }^{18} \mathrm{FDG}$ uptake per flask of treated cells (Figure 1A and B), with the greatest reduction occurring following $72 \mathrm{~h}$ exposure to epirubicin. Upon $48 \mathrm{~h}$ exposure to $\mathrm{LD}_{10}$ epirubicin, there was a non-significant reduction in ${ }^{18} \mathrm{FDG}$ uptake per flask $(P=0.104)$, with a significant reduction upon exposure to $\operatorname{LD}_{50}(P=0.006)$ compared with

Table I Chemotherapy dose-time relationship and cell death

\begin{tabular}{|c|c|c|c|}
\hline \multirow[b]{2}{*}{ Chemotherapy } & \multirow[b]{2}{*}{ Dose } & \multicolumn{2}{|c|}{ Cell death, \% ( \pm s.e.m.) } \\
\hline & & $48 \mathrm{~h}$ & $72 \mathrm{~h}$ \\
\hline Epirubicin & $\begin{array}{l}\mathrm{LD}_{10} \\
\mathrm{LD}_{50}\end{array}$ & $\begin{array}{r}4(4) \\
50(1)\end{array}$ & $\begin{array}{r}5(2) \\
69(10)\end{array}$ \\
\hline Cisplatin & $\begin{array}{l}\mathrm{LD}_{10} \\
\mathrm{LD}_{50}\end{array}$ & $\begin{array}{r}5(7) \\
56(7)\end{array}$ & $\begin{array}{c}5(4) \\
77(12)\end{array}$ \\
\hline 5-Fluorouracil & $\begin{array}{l}\mathrm{LD}_{10} \\
\mathrm{LD}_{50}\end{array}$ & $\begin{array}{r}9(8) \\
43(1)\end{array}$ & $\begin{array}{l}13(9) \\
55(6)\end{array}$ \\
\hline
\end{tabular}

Results of MTT assay performed at 48 and $72 \mathrm{~h}$.
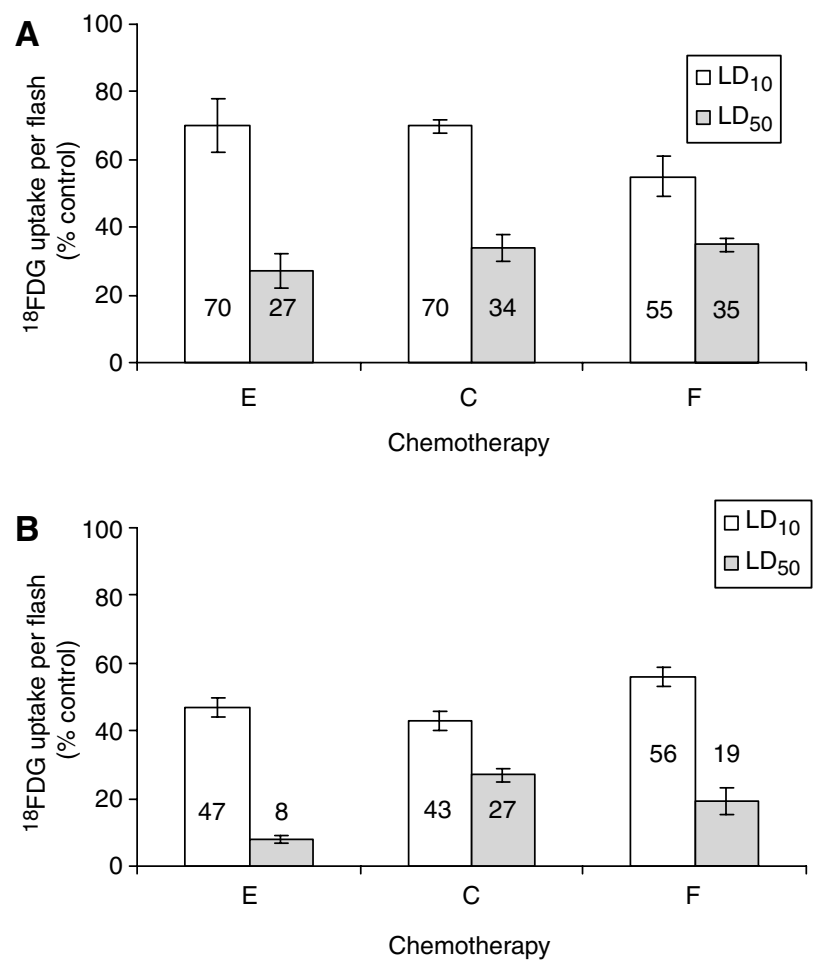

Figure I Cellular $\left[{ }^{18} \mathrm{~F}\right] 2$-fluoro-2-deoxy-D-glucose $\left({ }^{18} \mathrm{FDG}\right)$ incorporation, per treated flask, after $48(\mathbf{A})$ and 72 (B) $\mathrm{h}$ treatment with lethal dose 10 (LD,0) (white) and $\mathrm{LD}_{50}$ (grey) doses of epirubicin, 5-FU or cisplatin expressed as a percentage of incorporation by untreated controls $(E=$ epirubicin, $C=$ cisplatin, $F=5$-fluorouracil) 

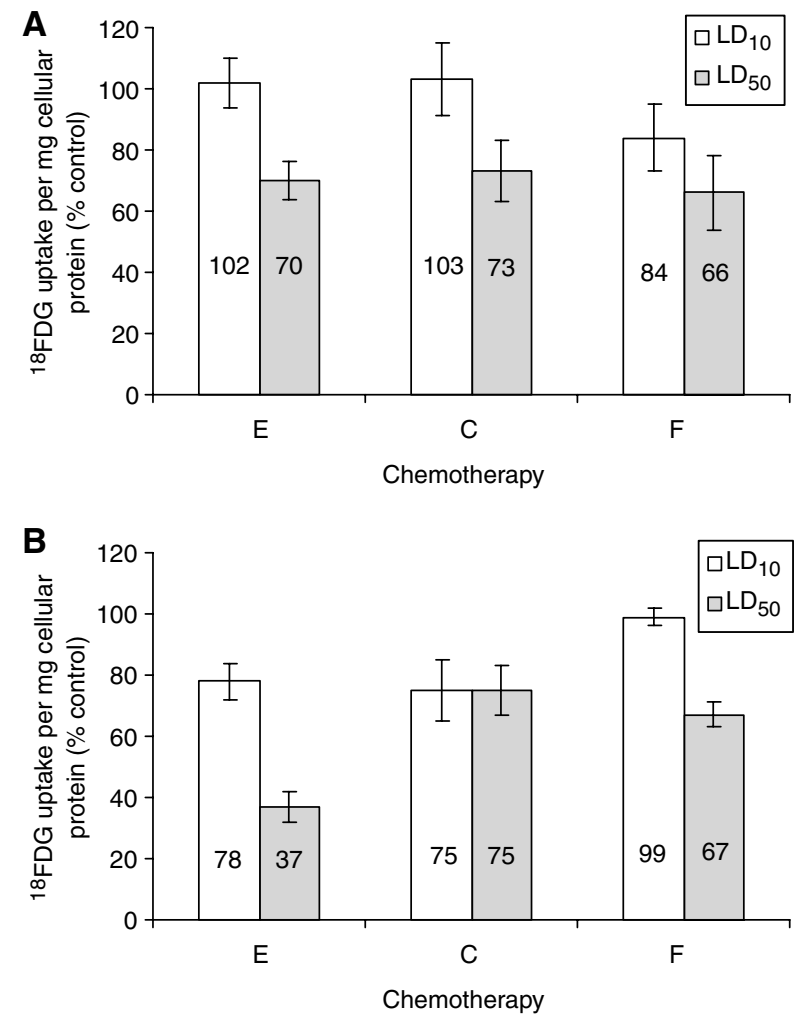

Figure 2 Cellular $\left[{ }^{18} \mathrm{~F}\right] 2$-fluoro-2-deoxy-D-glucose $\left({ }^{18} \mathrm{FDG}\right)$ incorporation, per milligram cellular protein, after $48(\mathbf{A})$ and $72(\mathbf{B}) \mathrm{h}$ treatment with lethal dose $10\left(\mathrm{LD}_{10}\right)$ (white) and $\mathrm{LD}_{50}$ (grey) doses of epirubicin, 5-FU or cisplatin expressed as a percentage of incorporation by untreated controls ( $E=$ epirubicin, $C=$ cisplatin, $F=5$-fluorouracil).

untreated controls. Both $48 \mathrm{~h} \mathrm{LD} D_{10}$ and $\mathrm{LD}_{50}$ exposure to cisplatin and 5 -FU resulted in a significant reduction in ${ }^{18} \mathrm{FDG}$ uptake per flask (cisplatin, $P=0.037$ and $P=0.001 ; 5-\mathrm{FU}, P=0.001$ and $P=0.001)$. Compared with untreated controls there was a significant reduction in ${ }^{18}$ FDG uptake per flask following $72 \mathrm{~h}$ $\mathrm{LD}_{10}$ and $\mathrm{LD}_{50}$ exposure to epirubicin $(P=0.001$ and $P=0.001$ respectively), cisplatin ( $P=0.001$ and $P=0.001$ respectively) and 5-FU $(P=0.001$ and $P=0.001$ respectively).

Exposure to all three chemotherapeutic agents resulted in a reduction in cellular ${ }^{18} \mathrm{FDG}$ uptake, with the greatest reduction $(63 \%)$ occurring on exposure to $\mathrm{LD}_{50}$ epirubicin after $72 \mathrm{~h}$ exposure (Figure $2 \mathrm{~A}$ and $\mathrm{B}$ ). This dose also produced a high level of cell death (69\%). Compared with untreated controls there was a significant reduction in ${ }^{18} \mathrm{FDG}$ uptake following $72 \mathrm{~h} \mathrm{LD}_{10}$ $(P=0.003)$ and both 48 and $72 \mathrm{~h}$ exposure to $\mathrm{LD}_{50}$ epirubicin ( $P=0.001$ and $P=0.011$ respectively), with a non-significant reduction in ${ }^{18} \mathrm{FDG}$ uptake following $48 \mathrm{~h}$ incubation at $\mathrm{LD}_{10}$ levels $(P=0.789) .{ }^{18}$ FDG uptake was significantly decreased in cells exposed to $\mathrm{LD}_{10}(P=0.01)$ and $\mathrm{LD}_{50}(P=0.001)$ doses of 5 -FU for $48 \mathrm{~h}$ exposure. Exposure to 5 -FU for $72 \mathrm{~h}$ resulted in a significant decrease in ${ }^{18} \mathrm{FDG}$ uptake at $\mathrm{LD}_{50}$ concentration $(P=0.001)$ whilst there was little difference between control and $\operatorname{LD}_{10}(P=0.839)$. Exposure for $48 \mathrm{~h}$ to cisplatin, $\mathrm{LD}_{10}$ had little effect on ${ }^{18} \mathrm{FDG}$ uptake $(P=0.636)$ in contrast to exposure of $L_{50}$, which resulted in a significant reduction in tracer uptake $(P=0.001)$. After $72 \mathrm{~h}$ exposure to cisplatin there was little further reduction in ${ }^{18} \mathrm{FDG}$ cellular uptake compared with exposure to $48 \mathrm{~h} \mathrm{LD}_{50}$.

\section{Effect of chemotherapy on cell cycle}

Exposure to $\mathrm{LD}_{50}$ cisplatin and epirubicin resulted in cell cycle arrest in $G_{2}$ phase, with $L_{10}$ doses resulting in $G_{1}$ arrest at both 48
Table 2 Cell cycle analysis following exposure to chemotherapeutic agents

\begin{tabular}{|c|c|c|c|c|c|}
\hline \multirow[b]{2}{*}{ Chemotherapy } & \multirow[b]{2}{*}{ Time (h) } & \multirow[b]{2}{*}{ Treatment } & \multicolumn{3}{|c|}{ Cell cycle, \% ( \pm s.e.m.) } \\
\hline & & & $\mathbf{G}_{1}$ & $\mathbf{s}$ & $\mathbf{G}_{2}$ \\
\hline Control & $\begin{array}{l}48 \\
72\end{array}$ & & $\begin{array}{l}50(1) \\
35(1)\end{array}$ & $\begin{array}{l}31(1) \\
30(2)\end{array}$ & $\begin{array}{l}19(1) \\
27(6)\end{array}$ \\
\hline 5-Fluorouracil & $\begin{array}{l}48 \\
72\end{array}$ & $\begin{array}{l}\mathrm{LD}_{10} \\
\mathrm{LD}_{50} \\
\mathrm{LD}_{10} \\
\mathrm{LD}_{50}\end{array}$ & $\begin{array}{l}36(2) \\
77(1) \\
14(1) \\
54(2)\end{array}$ & $\begin{array}{r}48(0) \\
9(0) \\
64(3) \\
14(3)\end{array}$ & $\begin{array}{l}14(1) \\
16(1) \\
19(1) \\
30(2)\end{array}$ \\
\hline Cisplatin & $\begin{array}{l}48 \\
72\end{array}$ & $\begin{array}{l}\mathrm{LD}_{10} \\
\mathrm{LD}_{50} \\
\mathrm{LD}_{10} \\
\mathrm{LD}_{50}\end{array}$ & $\begin{array}{l}57(0) \\
30(1) \\
48(1) \\
30(0)\end{array}$ & $\begin{array}{l}24(5) \\
22(0) \\
27(2) \\
16(0)\end{array}$ & $\begin{array}{l}19(6) \\
47(1) \\
24(1) \\
61(0)\end{array}$ \\
\hline Epirubicin & $\begin{array}{l}48 \\
72\end{array}$ & $\begin{array}{l}L_{10} \\
L_{10} \\
L D_{10} \\
L D_{50}\end{array}$ & $\begin{array}{l}59(0) \\
31(1) \\
46(1) \\
26(2)\end{array}$ & $\begin{array}{l}21(1) \\
13(3) \\
25(2) \\
10(1)\end{array}$ & $\begin{array}{l}21(0) \\
59(2) \\
28(1) \\
63(2)\end{array}$ \\
\hline
\end{tabular}

Flow cytometry was performed on a Becton Dickinson FACS Calibur (San Jose, CA, USA), using blue light $(488 \mathrm{~nm})$, detecting forward and $90^{\circ}$ angle light scatter. Cell cycle analysis was performed using Flowjo v4.5.2 analysis software (Tree Star Inc., OR, USA), utilising the Dean-Jett-Fox model, analysing 10000 events.

and $72 \mathrm{~h}$ incubation periods. $\mathrm{LD}_{10}$ dose of 5-FU resulted in $\mathrm{S}$ phase arrest, whilst the $L_{50}$ caused $G_{1}$ arrest, irrespective of incubation periods (Table 2).

\section{Effect of chemotherapy on glucose transport}

${ }^{3} \mathrm{H}-\mathrm{OMG}$ cellular uptake rate was reduced upon exposure to epirubicin, cisplatin and 5-FU, with the greatest reduction (35\%) in ${ }^{3} \mathrm{H}-\mathrm{OMG}$ uptake resulting from $72 \mathrm{~h}$ exposure to $\mathrm{LD}_{50}$ epirubicin (Figure $3 \mathrm{~A}$ and $\mathrm{B}$ ). Forty-eight hours exposure to $\mathrm{LD}_{50}$ epirubicin, cisplatin and 5-FU resulted in a significant reduction in cellular ${ }^{3} \mathrm{H}-\mathrm{OMG}$ uptake compared to controls $(P=0.037, P=0.005$ and $P=0.002$ respectively) as $\operatorname{did} 72 \mathrm{~h}$ exposure $(P=0.002, P=0.035$ and $P=0.001$ respectively). $L D_{10} 48 \mathrm{~h}$ exposure resulted in a nonsignificant decrease in ${ }^{3} \mathrm{H}-\mathrm{OMG}$ uptake for epirubicin, cisplatin and 5-FU ( $P=0.064, P=0.539$ and $P=0.05$ respectively). $\mathrm{LD}_{10}$ exposure at $72 \mathrm{~h}$ caused a significant reduction in uptake for epirubicin $(P=0.033)$ but not for cisplatin or $5-\mathrm{FU}(P=0.304$ and $P=0.212$ respectively).

\section{Effect of chemotherapy on cellular HK activity}

$\mathrm{LD}_{10} 48 \mathrm{~h}$ exposure to epirubicin, cisplatin and 5-FU resulted in a non-significant increase in cellular $\mathrm{HK}$ activity (Figure $4 \mathrm{~A}$ and $\mathrm{B})$ in comparison to controls $(P=0.575, P=0.982$ and $P=0.465$ respectively). Exposure to $48 \mathrm{~h} L_{50}$, cisplatin and 5-FU also caused a non-significant increase in cellular $\mathrm{HK}$ activity $(P=0.727$ and $P=0.282$ respectively) whereas with epirubicin there was a non-significant reduction in HK activity $(P=0.451)$.

Exposure to cisplatin and epirubicin for $72 \mathrm{~h}$ decreased $\mathrm{HK}$ activity, with the greatest reduction caused by exposure to $\mathrm{LD}_{50}$ cisplatin (65\%). Hexokinase activity was significantly reduced by exposure for $72 \mathrm{~h}$ to cisplatin and 5-FU (cisplatin $P=0.047$ and $P=0.011,5-\mathrm{FU} P=0.016$ and $P=0.018$ respectively for $\mathrm{LD}_{10}$ and $\mathrm{LD}_{50}$ ). Exposure for $72 \mathrm{~h}$ to epirubicin caused a significant reduction in $\mathrm{HK}$ activity with the $\mathrm{LD}_{50}$ dose $(P=0.02)$ but not the $\mathrm{LD}_{10}$ dose $(P=0.202)$. 

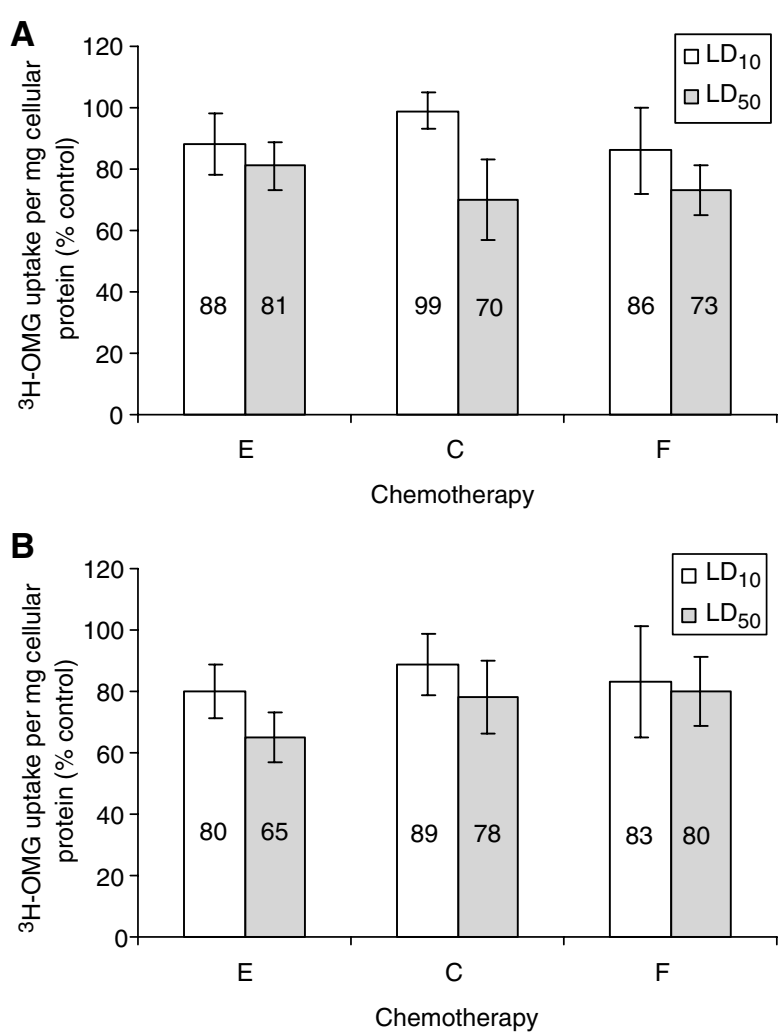

Figure 3 Cellular $\left[{ }^{3} \mathrm{H}\right] \mathrm{O}$-methylglucose $\left({ }^{3} \mathrm{H}-\mathrm{OMG}\right)$ uptake, per milligram of cellular protein, after $48(\mathbf{A})$ and $72(\mathbf{B}) \mathrm{h}$ incubation with lethal dose 10 $\left(L D_{10}\right)$ (white) and $L_{50}$ (grey) expressed as a percentage of the control $(E=$ epirubicin, $C=$ cisplatin, $F=5$-fluorouracil).
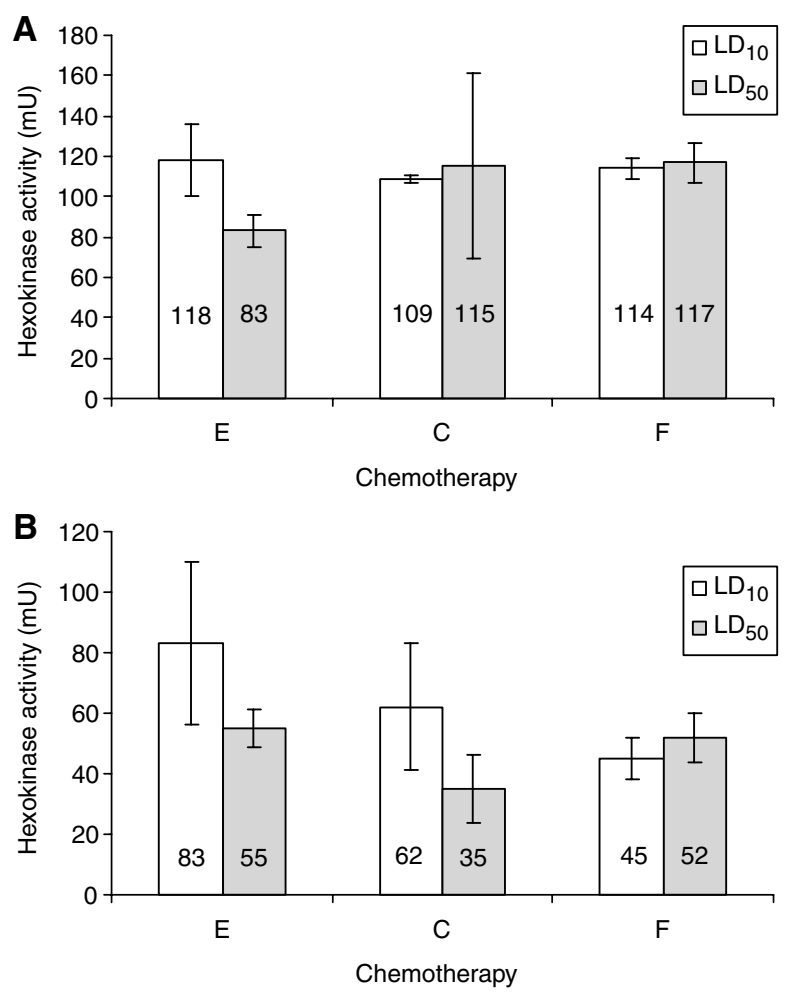

Figure 4 Cellular hexokinase (HK) activity, expressed as milliunits per milligram of cellular protein as a percentage of control $(E=$ epirubicin, $\mathrm{C}=$ cisplatin, $\mathrm{F}=5$-fluorouracil), after $48(\mathbf{A})$ and $72(\mathbf{B}) \mathrm{h}$ exposure to lethal dose $10\left(L_{10}\right)$ (white) and $L_{50}$ (grey) doses of epirubicin, cisplatin and 5-FU ( $\mathrm{E}=$ epirubicin, $\mathrm{C}=$ cisplatin, $\mathrm{F}=5$-fluorouracil).
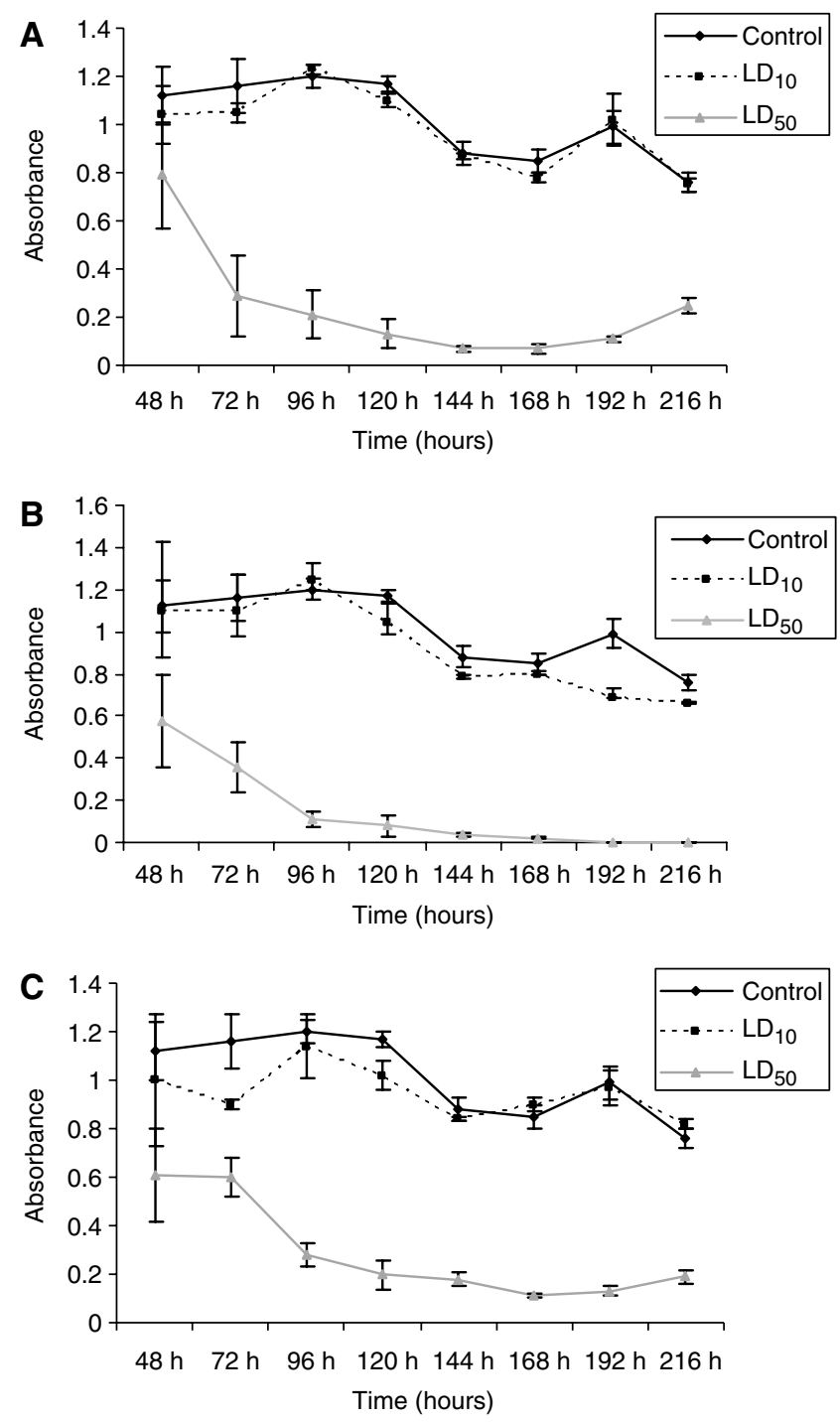

Figure 5 Determination of the growth inhibitory effect of each agent by performing MTT measurements 6 days after treatment with cisplatin $(\mathbf{A})$, epirubicin (B) and 5-FU (C) for $72 \mathrm{~h}$. Cell survival is expressed as absorbance as measured on spectrophotometer.

\section{Latent cytotoxicity of chemotherapeutic agents}

Following $72 \mathrm{~h}$ exposure to both $\mathrm{LD}_{10}$ and $\mathrm{LD}_{50}$ of each individual chemotherapeutic agent, cells were washed and fresh media was added followed by further incubation for up to 6 days. Cells were able to recover from exposure to 5-FU and cisplatin when the drug was removed. However, epirubicin-treated cells did not recover even after 6 days of incubation in fresh media (Figure 5A-C). Annexin V-PE flow cytometry revealed that AGS cells exposed to $72 \mathrm{~h} \mathrm{LD}_{50}$ epirubicin resulted in $69 \%$ cell death, $39 \%$ of surviving cells were annexin $\mathrm{V}-\mathrm{PE}$ positive and 7-AAD negative, indicating this group of cells were in the early stages of apoptosis (Table 3 ).

\section{DISCUSSION}

Chemotherapy for tumours at or around the gastro-oesophageal junction is varied, with most regimes including one of epirubicin, cisplatin or 5-FU (Cunningham et al, 2006). All three chemotherapeutic agents caused a reduction in ${ }^{18}$ FDG uptake by AGS cells with epirubicin having the greatest effect, followed by $5-\mathrm{FU}$ then 
Table 3 Results of annexin V-PE flow cytometry upon $72 \mathrm{~h}$ exposure to chemotherapy

Cells, \% ( \pm s.e.m.)

\begin{tabular}{lcccc} 
Chemotherapy Dose & $\begin{array}{c}\text { Annexin V-PE } \\
\text { and 7-AAD } \\
\text { negative }\end{array}$ & $\begin{array}{c}\text { Annexin V-PE } \\
\text { positive and } \\
\text { 7-AAD negative }\end{array}$ & $\begin{array}{c}\text { Annexin V-PE } \\
\text { and 7-AAD } \\
\text { positive }\end{array}$ \\
\hline Control & & $93(1)$ & $4(1)$ & $2(0)$ \\
Epirubicin & $L D_{10}$ & $94(1)$ & $2(1)$ & $4(0)$ \\
& $L D_{50}$ & $23(1)$ & $39(1)$ & $38(0)$ \\
Cisplatin & $L D_{10}$ & $95(0)$ & $3(0)$ & $2(0)$ \\
& $L D_{50}$ & $80(2)$ & $15(2)$ & $6(0)$ \\
5-Fluorouracil & $L D_{10}$ & $89(0)$ & $7(0)$ & $4(0)$ \\
& $L D_{50}$ & $93(2)$ & $3(1)$ & $4(2)$
\end{tabular}

Annexin V-PE FACS, 10000 events counted per sample with results displayed as a percentage of valid counts (annexin V-PE and 7-AAD negative $=$ healthy cells; annexin $\mathrm{V}$-PE positive and 7-AAD negative = early apoptosis; annexin V-PE and 7-AAD positive $=$ necrosis or late apoptosis).

cisplatin. Previous work on the AGS cell line using the same three chemotherapeutic agents and exposure times identified similar $\mathrm{LD}_{50}$ concentrations of each agent, 5-FU $10 \mu \mathrm{g} \mathrm{ml}^{-1}$, cisplatin $10 \mu \mathrm{g} \mathrm{ml}^{-1}$ and epirubicin $0.25 \mu \mathrm{g} \mathrm{ml}^{-1}$ (Couper and Park, 2003). In common with previous studies, exposure to epirubicin and cisplatin induced dose-dependent $\mathrm{G}_{1}\left(\mathrm{LD}_{10}\right)$ and $\mathrm{G}_{2}\left(\mathrm{LD}_{50}\right)$ cell cycle arrest (Barry et al, 1990; Sorenson et al, 1990; Shapiro et al, 1998; Zoli et al, 2004). 5-FU exposure resulted in a build up of cells in $S$ phase $\left(\mathrm{LD}_{10}\right)$ and $\mathrm{G}_{1}\left(\mathrm{LD}_{50}\right)$. Epirubicin, an anthracycline derivative of doxorubicin, exerts its anti-tumour effects via its action as a DNA intercalating agent and as an inhibitor of topoisomerase II (Cersosimo and Hong, 1986; Bartkowiak et al, 1992; Zoli et al, 2004). The arrest of AGS cells at higher concentrations of epirubicin may be related to peak activity of topoisomerases occurring during the $\mathrm{G}_{2}$ phase (Chow and Ross, 1987). Exposure to cisplatin, an alkylating agent, results in the binding of cisplatin to DNA, forming cisplatin-DNA adducts which causes an alteration in the conformation of DNA leading to cell cycle arrest and apoptosis (Jordan and Carmo-Fonseca, 2000; Gonzalez et al, 2001; Wang et al, 2004). Cell cycle arrest following exposure to cisplatin occurs mainly within $\mathrm{G}_{2}$ (Eastman, 1990; Sorenson et al, 1990), although this may be tumour type dependent (Sekiguchi et al, 1996; Shapiro et al, 1998). The main mechanism of action of 5-FU is related to its conversion to 5-fluoro- $2^{\prime}$-deoxy$5^{\prime}$-monophosphate (via the pyrimidine pathway) leading to the inhibition of thymidylate synthase and hence DNA synthesis (Pinedo and Peters, 1988). Studies have revealed an increase S-phase fraction in tumour cells, caused by 5-FU (Barry et al, 1990; Yamane et al, 1999; Park et al, 2004), including gastric carcinomas (Inada et al, 1997).

Dittmann et al (2002), evaluating ${ }^{18} \mathrm{FDG}$ uptake in a squamous cell carcinoma oesophageal cell line, reported that $24 \mathrm{~h}$ incubation periods in concentrations of 5-FU and cisplatin, resulting in 22.8 and $60.6 \%$ cell death respectively, had no effect on cellular ${ }^{18} \mathrm{FDG}$ uptake, following a $24 \mathrm{~h}$ period of incubation in chemotherapy-free media prior to uptake experiments. Furthermore, after $24 \mathrm{~h}$ exposure to these same concentrations of drugs the S-phase fraction was elevated considerably, yet had no impact on ${ }^{18} \mathrm{FDG}$ uptake. Smith et al (2000) investigating tomudex, which is a more specific thymidylate synthase inhibitor than 5 -FU, and oxaliplatin (a platinum agent similar to cisplatin) on a colonic tumour cell line found that exposure to tomudex for 24 and $48 \mathrm{~h}$ resulted in increasing levels of cellular ${ }^{3} \mathrm{H}-\mathrm{DG}$ uptake with increasing exposure to the agent. This increase in uptake was paralleled with an increase in the S-phase fraction. The contrasts between these studies and ours may be in part explained by Yamane et al (1999), who revealed that although increasingly lengthy exposure to 5-FU resulted in S-phase accumulation of colorectal cancer cells with increased apoptosis, the Ki-67 labelling index decreased. Therefore, this S-phase accumulation is not proliferative but lethal. Exposure to oxaliplatin (Smith et al, 2000) resulted in decreased levels of cellular ${ }^{3} \mathrm{H}-\mathrm{DG}$ uptake compared to controls with a varied cell cycle distribution. Although ${ }^{18}$ FDG uptake in this study was found to be decreased after treatment with each agent, the effect on cell cycle was agent-specific suggesting that the changes in ${ }^{18} \mathrm{FDG}$ uptake are not cell cycle-specific, a finding previously reported by others (Higashi et al, 1993; Haberkorn et al, 1994).

Recently an analysis (Barros et al, 2005) based on the relationship between HK, glucose transport and intracellular glucose concentration shows that, at least in neuronal cells, the flux of glucose through the cell is dependent both on $\mathrm{HK}$ and glucose transport and that appreciable increases in flux require increases in both of these activities, whereas decreased flux can be brought about by a reduction in glucose transport or HK activity or both. Qualitatively, in our study, in each case where a decrease in ${ }^{18} \mathrm{FDG}$ incorporation is observed there is a corresponding decrease in glucose transport. By far the greatest decrease in ${ }^{18} \mathrm{FDG}$ incorporation is observed with the $\mathrm{LD}_{50}$ dose of epirubicin for $72 \mathrm{~h}$, which also marginally shows the greatest reduction in glucose transport. This treatment also causes an appreciable decrease in HK activity, which may augment the effect of glucose transport on ${ }^{18} \mathrm{FDG}$ incorporation. However, the lack of effect of the $\mathrm{LD}_{10}$ dose of 5 -FU for $72 \mathrm{~h}$ on ${ }^{18} \mathrm{FDG}$ incorporation or glucose transport, which caused a significant decrease in HK activity, suggests that glucose transport is the most important parameter for ${ }^{18} \mathrm{FDG}$ incorporation in this cell line. Further, regression analysis performed on pooled 48 and $72 \mathrm{~h}$ data from each treatment shows a strong correlation between the changes in FDG incorporation and glucose transport $(t=0.863, n=12, P<0.001)$ but not between changes in FDG incorporation and HK activity $(t=0.31, n=12$, $P>0.1$.

One possible reason for the closer association of glucose transport with ${ }^{18}$ FDG incorporation compared with HK activity may be that the glucose transport assay uses intact cells so is a true measure of the glucose transport of the AGS cell, whereas the HK assay is performed in cell homogenates. Since HK activity in vivo is compartmentalised and highly regulated (Smith, 2000), cell breakage is likely to disrupt these regulatory systems.

We found that ${ }^{18} \mathrm{FDG}$ incorporation was consistently diminished by treatment with epirubicin, 5-FU or cisplatin. We did not see any evidence of increased incorporation. Although response to therapy is generally associated with decreased ${ }^{18} \mathrm{FDG}$ incorporation, a number of studies (Basu and Alavi, 2007) have reported that ${ }^{18}$ FDG incorporation can increase in some responding tumours. In cases where this 'metabolic flare' phenomenon has been observed in breast tumours treated with anti-oestrogen treatment it has been attributed to the stimulatory effect of the anti-oestrogen at low blood concentrations (the situation when the patient begins therapy) on their cancer cells. A flare phenomenon occasionally found after radiotherapy generally corresponds with influx of inflammatory cells into the tumour (Kostakoglu and Goldsmith, 2004). Kubota et al (1992) studying ${ }^{18}$ FDG uptake in a malignant murine model discovered that ${ }^{18} \mathrm{FDG}$ accumulated not only within the tumour cells, but also in the inflammatory components which appear with growth or tumour necrosis; however, the major source of ${ }^{18}$ FDG was still tumour cells. Clearly neither of these situations is relevant to our treatment/model type.

Another type of hypermetabolism associated with ${ }^{18}$ FDG has been reported in both solid tumours (Maruyama et al, 1999) and cell lines (Fujibayashi et al, 1997). This is likely to reflect biochemical changes within the cells in response to initial damage. We determined ${ }^{18}$ FDG incorporation at times corresponding to 
appreciable cell death so the initial response would have been complete.

Comparing ${ }^{18}$ FDG incorporation after 48 and $72 \mathrm{~h}$ of treatment, when expressed relative to cellular protein, the decrease in ${ }^{18} \mathrm{FDG}$ incorporation is seen to plateau for treatment with cisplatin and 5 -FU but not with epirubicin in which ${ }^{18} \mathrm{FDG}$ incorporation continues to decline. This may be explained by the high proportion (77\%) of apoptotic cells in cell populations treated with $\mathrm{LD}_{50}$ epirubicin for $72 \mathrm{~h}$ compared with cells exposed to cisplatin and 5 -FU, suggesting that ${ }^{18} \mathrm{FDG}$ incorporation by apoptotic cells is decreased compared with viable cells. Following on from this, determination of the growth inhibitory effect of each agent by performing MTT measurements 6 days after treatment with each agent showed that AGS cells can recover from treatment with 5-FU and cisplatin but not after treatment with epirubicin. In assessing two chemotherapy regimens for gastro-oesophageal cancer, Couper and Park (2003) noted that AGS cells exposed to a combination of $\mathrm{LD}_{50}$ of both cisplatin and 5-FU were able to recover following clearance of the chemotherapy. The addition of epirubicin to the combination of cisplatin and 5-FU resulted in a continual growth inhibitory effect (Couper and Park, 2003). The nature of Coupers' study meant that this effect may be due to the combined effect of three chemotherapeutic agents rather than specifically related to epirubicin. Engles et al treated MCF-7 breast carcinoma cells for $24 \mathrm{~h}$ with doxorubicin (an anthracycline similar to epirubicin) and 5-FU then re-incubated the cells in chemotherapy-free medium for a further $72 \mathrm{~h}$. They found that cell number in populations treated with doxorubicin continued to decrease during the $72 \mathrm{~h}$ in doxorubicin-free medium (Engles et al, 2006), but addition of 5-FU-free media to MCF-7 cells treated for $24 \mathrm{~h}$ with 5 -FU was associated with an increase in cell number indicative of recovery. It appears that the efficacy of epirubicin is associated with reduced cellular glycolytic rate (Zhou et al, 2002).

One of the limitations of our study is the extrapolation from in vitro to in vivo. Our studies are performed on well-perfused cells with a good nutrient and oxygen supply in an environment with neutral $\mathrm{pH}$. Within solid tumours in vivo there are regions with compromised blood flow and consequent nutrient deprivation, lactic acid production and acidic $\mathrm{pH}$. These are all factors that may influence ${ }^{18} \mathrm{FDG}$ incorporation. Burgman et al (2001) showed that induction of hypoxia resulted in increased ${ }^{18} \mathrm{FDG}$ incorporation by MCF-7 cells whilst HK activity is influenced by environmental $\mathrm{pH}$ (Miccoli et al, 1996). However, the region of tumour growth will have a good blood supply and is where most of the ${ }^{18} \mathrm{FDG}$ is likely to reach.

To simulate the uptake of ${ }^{18}$ FDG within solid tumours, ${ }^{18} \mathrm{FDG}$ uptake was also expressed as activity per flask. The uptake of ${ }^{18}$ FDG by detached cells could not be determined as steps to wash away non-incorporated ${ }^{18} \mathrm{FDG}$ would involve centrifugation, which would be a problem with detached cells as these are generally late dying/dead cells with fragile or damaged cell membranes. However, cells that were undergoing early apoptosis, for example, cells treated with epirubicin, were still attached and would be included in the analyses. Furthermore, in vivo, dead cells are rapidly removed by macrophages. So the contribution of dead cells in vivo is likely to be small.

In summary, treatment of gastric adenocarcinoma cells with cisplatin, 5-FU and epirubicin results in decreased ${ }^{18} \mathrm{FDG}$ incorporation. The greatest reduction in ${ }^{18} \mathrm{FDG}$ uptake per cell is induced by epirubicin. In contrast to cisplatin and 5-FU treated cells, epirubicin-treated cells did not recover when the drug was removed from the medium, corresponding with the annexin V-PE results, suggesting that the level of change in ${ }^{18} \mathrm{FDG}$ incorporation is predictive of tumour cell response. Each chemotherapeutic agent decreased glucose transport suggesting that glucose transport is the rate-limiting step for ${ }^{18} \mathrm{FDG}$ incorporation by AGS cells.

\section{ACKNOWLEDGEMENTS}

This work was supported by Association of International Cancer Research grant 04-300 and patient donations to the Department of Upper Gastro-Intestinal Surgery, Aberdeen Royal Infirmary, United Kingdom.

\section{REFERENCES}

Al-Saeedi F, Welch AE, Smith TA (2005) [methyl-(3)H]Choline incorporation into MCF7 tumour cells: correlation with proliferation. Eur J Nucl Med Mol Imaging 32: 660-667

Aloj L, Caraco C, Jagoda E, Eckelman WC, Neumann RD (1999) Glut-1 and hexokinase expression: relationship with 2-fluoro-2-deoxy-D-glucose uptake in A431 and T47D cells in culture. Cancer Res 59: 4709-4714

Barros LF, Porras OH, Bittner CX (2005) Why glucose transport in the brain matters for PET. Trends Neurosci 28: 117-119

Barry MA, Behnke CA, Eastman A (1990) Activation of programmed cell death (apoptosis) by cisplatin, other anticancer drugs, toxins and hyperthermia. Biochem Pharmacol 40: 2353-2362

Bartkowiak D, Hemmer J, Rottinger E (1992) Dose dependence of the cytokinetic and cytotoxic effects of epirubicin in vitro. Cancer Chemother Pharmacol 30: 189-192

Basu S, Alavi A (2007) Defining co-related parameters between 'metabolic' flare and 'clinical', 'biochemical', and 'osteoblastic' flare and establishing guidelines for assessing response to treatment in cancer. Eur J Nucl Med Mol Imaging 34: $441-443$

Brown RS, Leung JY, Kison PV, Zasadny KR, Flint A, Wahl RL (1999) Glucose transporters and FDG uptake in untreated primary human nonsmall cell lung cancer. $\mathrm{J} \mathrm{Nucl} \mathrm{Med} \mathrm{40:} \mathrm{556-565}$

Burgman P, Odonoghue JA, Humm JL, Ling CC (2001) Hypoxia-Induced increase in FDG uptake in MCF7 cells. J Nucl Med 42: 170-175

Burrows RC, Freeman SD, Charlop AW, Wiseman RW, Adamsen TC, Krohn KA, Spence AM (2004) [18F]-2-fluoro-2-deoxyglucose transport kinetics as a function of extracellular glucose concentration in malignant glioma, fibroblast and macrophage cells in vitro. Nucl Med Biol 31: 1-9
Carmichael J, DeGraff WG, Gazdar AF, Minna JD, Mitchell JB (1987) Evaluation of a tetrazolium-based semiautomated colorimetric assay: assessment of chemosensitivity testing. Cancer Res 47: 936-942

Cersosimo RJ, Hong WK (1986) Epirubicin: a review of the pharmacology, clinical activity, and adverse effects of an adriamycin analogue. $J$ Clin Oncol 4: $425-439$

Chow KC, Ross WE (1987) Topoisomerase-specific drug sensitivity in relation to cell cycle progression. Mol Cell Biol 7: 3119-3123

Cloherty EK, Levine KB, Graybill C, Carruthers A (2002) Cooperative nucleotide binding to the human erythrocyte sugar transporter. Biochemistry 41: 12639-12651

Couper G, Park K (2003) In vitro response to chemotherapy: evidence of resistance to neo-adjuvant chemotherapy in upper gastrointestinal cancer. Br J Surg 90: 50

Couper GW, McAteer D, Wallis F, Norton M, Welch A, Nicolson M, Park KG (1998) Detection of response to chemotherapy using positron emission tomography in patients with oesophageal and gastric cancer. $\mathrm{Br}$ J Surg 85: $1403-1406$

Cunningham D, Allum WH, Stenning SP, Thompson JN, Van de Velde CJ, Nicolson M, Scarffe JH, Lofts FJ, Falk SJ, Iveson TJ, Smith DB, Langley RE, Verma M, Weeden S, Chua YJ, Participants MT (2006) Perioperative chemotherapy vs surgery alone for resectable gastroesophageal cancer. $N$ Engl J Med 355: $11-20$

Dittmann H, Dohmen BM, Kehlbach R, Bartusek G, Pritzkow M, Sarbia M, Bares R (2002) Early changes in [18F]FLT uptake after chemotherapy: an experimental study. Eur J Nucl Med Mol Imaging 29: $1462-1469$ 
Eastman A (1990) Activation of programmed cell death by anticancer agents: cisplatin as a model system. Cancer Cells 2: 275-280

Engles JM, Quarless SA, Mambo E, Ishimori T, Cho SY, Wahl RL (2006) Stunning and its effect on 3H-FDG uptake and key gene expression in breast cancer cells undergoing chemotherapy. J Nucl Med 47: 603-608

Fujibayashi Y, Waki A, Sakahara H, Konishi J, Yonekura Y, Ishii Y, Yokoyama A (1997) Transient increase in glycolytic metabolism in cultured tumor cells immediately after exposure to ionizing radiation: from gene expression to deoxyglucose uptake. Radiat Res 147: 729-734

Gallagher BM, Fowler JS, Gutterson NI, MacGregor RR, Wan CN, Wolf AP (1978) Metabolic trapping as a principle of oradiopharmaceutical design: some factors resposible for the biodistribution of [18F] 2-deoxy-2fluoro-D-glucose. J Nucl Med 19: 1154-1161

Gilbert FJ, Park K, Thompson AM (2002) Scottish Audit of Gastric and Oesophageal Cancer: Report 1997-2000 - A prospective audit. http:// www.show.scot.nhs.uk/crag/

Gonzalez VM, Fuertes MA, Alonso C, Perez JM (2001) Is cisplatin-induced cell death always produced by apoptosis? Mol Pharmacol 59: 657-663

Haberkorn U, Oberdorfer F, Klenner T, Strauss LG, Stohr M, Wallich R, Altmann A, Kaick GV (1994) Metabolic and transcriptional changes in osteosarcoma cells treated with chemotherapeutic drugs. Nucl Med Biol 21: $835-845$

Higashi K, Clavo AC, Wahl RL (1993) Does FDG uptake measure proliferative activity of human cancer cells? In vitro comparison with DNA flow cytometry and tritiated thymidine uptake. J Nucl Med 34: 414- 419

Higashi T, Tamaki N, Honda T, Torizuka T, Kimura T, Inokuma T, Ohshio G, Hosotani R, Imamura M, Konishi J (1997) Expression of glucose transporters in human pancreatic tumors compared with increased FDG accumulation in PET study. I Nucl Med 38: 1337-1344

Inada T, Ichikawa A, Igarashi S, Kubota T, Ogata Y (1997) Effect of preoperative 5-fluorouracil on apoptosis of advanced gastric cancer. J Surg Oncol 65: $106-110$

Jordan P, Carmo-Fonseca M (2000) Molecular mechanisms involved in cisplatin cytotoxicity. Cell Mol Life Sci 57: 1229-1235

Kostakoglu L, Goldsmith SJ (2004) PET in the assessment of therapy response in patients with carcinoma of the head and neck and of the esophagus. J Nucl Med 45: 56-68

Kroep JR, Van Groeningen CJ, Cuesta MA, Craanen ME, Hoekstra OS, Comans EF, Bloemena E, Hoekstra CJ, Golding RP, Twisk JW, Peters GJ, Pinedo HM, Lammertsma AA (2003) Positron emission tomography using 2-deoxy-2-[18F]-fluoro-D-glucose for response monitoring in locally advanced gastroesophageal cancer; a comparison of different analytical methods. Mol Imaging Biol 5: 337-346

Kubota R, Yamada S, Kubota K, Ishiwata K, Tamahashi N, Ido T (1992) Intratumoral distribution of fluorine-18-fluorodeoxyglucose in vivo: high accumulation in macrophages and granulation tissues studied by microautoradiography. J Nucl Med 33: $1972-1980$

Kurokawa T, Yoshida Y, Kawahara K, Tsuchida T, Okazawa H, Fujibayashi Y, Yonekura Y, Kotsuji F (2004) Expression of GLUT-1 glucose transfer, cellular proliferation activity and grade of tumor correlate with [F-18]fluorodeoxyglucose uptake by positron emission tomography in epithelial tumors of the ovary. Int J Cancer 109: 926-932

Maruyama I, Sadato N, Waki A, Tsuchida T, Yoshida M, Fujibayashi Y, Ishii Y, Kubota T, Yonekura Y (1999) Hyperacute changes in glucose metabolism of brain tumors after stereotactic radiosurgery: a PET study. I Nucl Med 40: 1085 - 1090

Mathupala SP, Rempel A, Pedersen PL (1997) Aberrant glycolytic metabolism of cancer cells: a remarkable coordination of genetic, transcriptional, post-translational, and mutational events that lead to a critical role for type II hexokinase. J Bioenerg Biomembr 29: 339-343

Miccoli L, Oudard S, Sureau F, Poirson F, Dutrillaux B, Poupon MF (1996) Intracellular $\mathrm{pH}$ governs the subcellular distribution of hexokinase in a glioma cell line. Biochem J 313(Part 3): 957-962

Mosmann T (1983) Rapid colorimetric assay for cellular growth and survival: application to proliferation and cytotoxicity assays. J Immunol Methods 65: 55-63

Mueckler M (1994) Facilitative glucose transporters. Eur J Biochem 219: $713-725$

Nelson CA, Wang JQ, Leav I, Crane PD (1996) The interaction among glucose transport, hexokinase, and glucose-6-phosphatase with respect to $3 \mathrm{H}$-2-deoxyglucose retention in murine tumor models. Nucl Med Biol 23: $533-541$

Ott K, Fink U, Becker K, Stahl A, Dittler HJ, Busch R, Stein H, Lordick F, Link T, Schwaiger M, Siewert JR, Weber WA (2003) Prediction of response to preoperative chemotherapy in gastric carcinoma by metabolic imaging: results of a prospective trial. J Clin Oncol 21: 4604-4610

Park JK, Lee SH, Kang JH, Nishio K, Saijo N, Kuh HJ (2004) Synergistic interaction between gefitinib (Iressa, ZD1839) and paclitaxel against human gastric carcinoma cells. Anticancer Drugs 15: 809-818

Pinedo HM, Peters GF (1988) Fluorouracil: biochemistry and pharmacology. J Clin Oncol 6: 1653-1664

Sekiguchi I, Suzuki M, Tamada T, Shinomiya N, Tsuru S, Murata M (1996) Effects of cisplatin on cell cycle kinetics, morphological change, and cleavage pattern of DNA in two human ovarian carcinoma cell lines. Oncology 53: 19-26

Shapiro GI, Edwards CD, Ewen ME, Rollins BJ (1998) p16INK4A participates in a G1 arrest checkpoint in response to DNA damage. Mol Cell Biol 18: 378-387

Smith TA (1999) Facilitative glucose transporter expression in human cancer tissue. Br J Biomed Sci 56: 285-292

Smith TA (2000) Mammalian hexokinases and their abnormal expression in cancer. Br J Biomed Sci 57: 170-178

Smith TA, Maisey NR, Titley JC, Jackson LE, Leach MO, Ronen SM (2000) Treatment of SW620 cells with Tomudex and oxaliplatin induces changes in 2-deoxy-D-glucose incorporation associated with modifications in glucose transport. J Nucl Med 41: 1753-1759

Smith TA, Sharma RI, Thompson AM, Paulin FE (2006) Tumor 18F-FDG incorporation is enhanced by attenuation of P53 function in breast cancer cells in vitro. J Nucl Med 47: 1525-1530

Sorenson CM, Barry MA, Eastman A (1990) Analysis of events associated with cell cycle arrest at G2 phase and cell death induced by cisplatin. $J$ Natl Cancer Inst 82: 749-755

Tohma T, Okazumi S, Makino H, Cho A, Mochiduki R, Shuto K, Kudo H, Matsubara K, Gunji H, Ochiai T (2005) Relationship between glucose transporter, hexokinase and FDG-PET in esophageal cancer. Hepatogastroenterology 52: $486-490$

Torizuka T, Tamaki N, Inokuma T, Magata Y, Sasayama S, Yonekura Y, Tanaka A, Yamaoka Y, Yamamoto K, Konishi J (1995) In vivo assessment of glucose metabolism in hepatocellular carcinoma with FDG-PET. J Nucl Med 36: $1811-1817$

Waki A, Kato H, Yano R, Sadato N, Yokoyama A, Ishii Y, Yonekura Y, Fujibayashi Y (1998) The importance of glucose transport activity as the rate-limiting step of 2-deoxyglucose uptake in tumor cells in vitro. $\mathrm{Nucl}$ Med Biol 25: 593-597

Wang G, Reed E, Li QQ (2004) Molecular basis of cellular response to cisplatin chemotherapy in non-small cell lung cancer (Review). Oncol Rep 12: $955-965$

Warburg O (1956) On the origin of cancer cells. Science 123: 306-314

Weber G, Cantero A (1955) Glucose-6-phosphatase activity in normal, precancerous, and neoplastic tissues. Cancer Res 15: 105-108

Weber WA, Ott K, Becker K, Dittler HJ, Helmberger H, Avril NE, Meisetschlager G, Busch R, Siewert JR, Schwaiger M, Fink U (2001) Prediction of response to preoperative chemotherapy in adenocarcinomas of the esophagogastric junction by metabolic imaging. J Clin Oncol 19: $3058-3065$

Yamane N, Makino M, Kaibara N (1999) S-phase accumulation precedes apoptosis induced by preoperative treatment with 5 -fluorouracil in human colorectal carcinoma cells. Cancer 85: 309-317

Younes M, Lechago LV, Somoano JR, Mosharaf M, Lechago J (1996) Wide expression of the human erythrocyte glucose transporter Glut1 in human cancers. Cancer Res 56: 1164-1167

Zhao S, Kuge Y, Mochizuki T, Takahashi T, Nakada K, Sato M, Takei T, Tamaki N (2005) Biologic correlates of intratumoral heterogeneity in 18F-FDG distribution with regional expression of glucose transporters and hexokinase-II in experimental tumor. J Nucl Med 46: $675-682$

Zhao S, Kuge Y, Tsukamoto E, Mochizuki T, Kato T, Hikosaka K, Nakada K, Hosokawa M, Kohanawa M, Tamaki N (2002) Fluorodeoxyglucose uptake and glucose transporter expression in experimental inflammatory lesions and malignant tumours: effects of insulin and glucose loading. Nucl Med Commun 23: 545-550

Zhou R, Vander Heiden MG, Rudin CM (2002) Genotoxic exposure is associated with alterations in glucose uptake and metabolism. Cancer Res 62: $3515-3520$

Zoli W, Ricotti L, Tesei A, Ulivi P, Gasperi Campani A, Fabbri F, Gunelli R, Frassineti GL, Amadori D (2004) Schedule-dependent cytotoxic interaction between epidoxorubicin and gemcitabine in human bladder cancer cells in vitro. Clin Cancer Res 10: $1500-1507$ 